\title{
FLEXURAL BEHAVIOUR OF RC BEAMS USING FOUNDRY SAND AS PARTIAL REPLACEMENT OF FINE AGGREGATE
}

\author{
Umashankar A ${ }^{1}$, Shashikumar A ${ }^{2}$, G Narayana ${ }^{3}$ \\ ${ }^{1}$ Post graduate Student, Department of Civil Department, S.J.C.I.T, Chickballapura, Karnataka, India \\ ${ }^{2}$ Assistant Professor, Department of Civil Department, S.J.C.I.T, Chickballapura, Karnataka, India \\ ${ }^{3}$ Professor \& Head of Department of Civil Engineering, S.J.C.I.T, Chickballapura, Karnataka, India
}

\begin{abstract}
The main objective of the study of this work is to re-use the used foundry sand (produced at foundry industries) as a partial replacement to fine aggregate in different percentages (15 to 50\%) that can be adopted in concrete along with normal river sand designed to meet the requirements of concrete of grade M50, using foundry sand with OPC have been considered in the study. Though, the main investigation is to be carried out is on the flexural behavior of reinforced foundry sand concrete beams, to facilitate proportioning of foundry sand concrete, compressive strength studies are also carried out. The tests to be carried out on around (18) singly reinforced beams of size $150 \mathrm{~mm} \times 250 \mathrm{~mm}$ \& overall length $2000 \mathrm{~mm}$, simply supported over effective span $1800 \mathrm{~mm}$ under pure bending. The beams will be provided with adequate shear reinforcement so that the failure of the beams may due to pure flexure. The grade of concrete M50 generally with three foundry sand replacement levels (FSL) in each grade i,e, $15 \%, 25 \%$, \& $35 \%$ FSL are considered.
\end{abstract}

Keywords: Flexural, Foundry Sand, Fine Aggregate.

\section{INTRODUCTION}

Foundries for the metallic-casting industry generate with the aid of merchandise adore used foundry sand. Steel foundries use first-class deal of the metal casting process. Foundries with success recycle and recycle the sand over and over in an awfully mill and thus the rest sand that is termed as foundry sand is a long way from mill. Use of foundry sand in numerous engineering purposes will resolve the subject of disposal of foundry sand and one-of-a-kind features.

Foundry sand consists above all of silicon dioxide sand, coated with a thin film of burnt carbon, residual and filth. Foundry sand may be employed in concrete to increase its strength and special sturdiness motives. Foundry Sand may be used as a partial replacement of high-quality mixtures or whole alternative of fine aggregate and as supplementary addition to gain completely distinct houses of concrete.

Power performs a central position in era of setting up countries like Asian nation. By way of earning carbon credit score with the aid of victimization industrial waste used Foundry sand for constructing materials like exceptional mixture, the energy \&amp; setting may be saved. Concrete may be a composite construction fabric composed of cement, mixture (on the whole a hard combination product of gravels or crushed rocks adore sedimentary rock, or granite, and a fine combo adore sand), water, and/or admixtures. Concrete is created by way of mixing: Cement, water, course great aggregates and admixtures (if required). The goals square measure to mix these materials traditionally to create concrete that is easy to: Transport, position, compact, and finish and to provide a robust and sturdy product. The proportionate quantity of every material (i.e. Cement, water and aggregates) impacts the properties of hardened concrete.

This Foundry sand consumes an outsized share of native lowland subject for every and each and every yr. Worse but, a number of the wastes square measure land unfold on cropland as a disposal procedure, raising concerns involving hint contaminants expand in soil or walking off into house lakes and streams. Some industries burn their sludge in incinerators, conducive to our severe pollution problems. To shrink disposal and pollution problems emanating from these industrial wastes, it can be most essential to boost beneficial constructing substances from them. Keeping this visible, investigations have been undertaken to give low price concrete by mixing numerous ratios of first-rate mixture with used foundry sand.

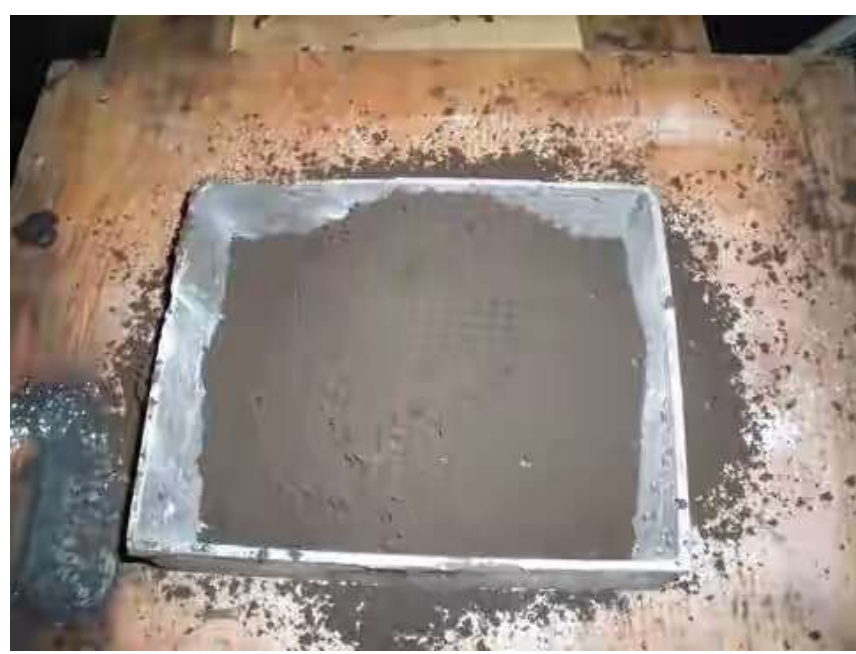

Fig.1 Foundry sand 
Table 1.1 Chemical compound compositions in foundry sand

\begin{tabular}{|l|l|}
\hline CONSTITUENT & VALUE (\%) \\
\hline $\mathrm{SiO} 2$ & 87.93 \\
\hline $\mathrm{A} 2 \mathrm{O} 3$ & 4.70 \\
\hline $\mathrm{Fe} 2 \mathrm{O} 3$ & 0.94 \\
\hline $\mathrm{CaO}$ & 0.12 \\
\hline $\mathrm{MgO}$ & 0.30 \\
\hline $\mathrm{SO} 3$ & 0.09 \\
\hline $\mathrm{Na} 2 \mathrm{O}$ & 0.19 \\
\hline $\mathrm{K} 2 \mathrm{O}$ & 0.21 \\
\hline $\mathrm{TiO} 2$ & 0.15 \\
\hline $\mathrm{P} 2 \mathrm{O} 5$ & 0.00 \\
\hline $\mathrm{Mn} 2 \mathrm{O} 3$ & 0.06 \\
\hline $\mathrm{SrO}$ & 0.03 \\
\hline LOI & 5.15 \\
& $9.47) 2.1-12.1$ \\
\hline TOTAL & $\mathbf{9 9 . 8 7}$ \\
\hline
\end{tabular}

\subsection{Flexural Reinforcement}

\subsubsection{Concrete Cover}

Clear cover is that the space from the uncovered concrete floor to the closest surface of the reinforcing bar. This duvet is required to look after the strengthened bars from the corrosion, hearth and additionally to furnish the reinforced bars for cozy embedment to modify them to worry whilst now not 'slipping' (shedding bond with the concrete).

A bit is purported to be balanced section if a equivalent applied moment the strain within the concrete and inside the metal reach their limiting values at the same time. The failure of the balanced section is termed as "balanced failure", is predicted to arise with the aid of the taking place initiation of the crushing and yielding of metal.

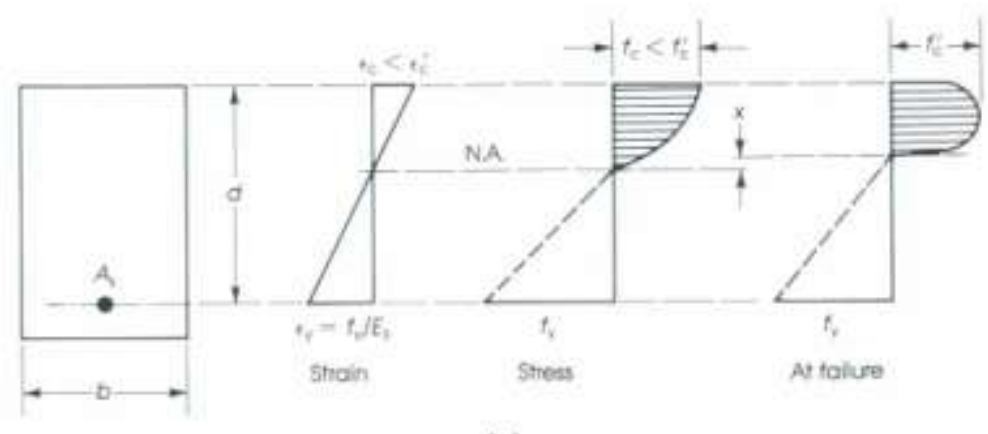

(a)

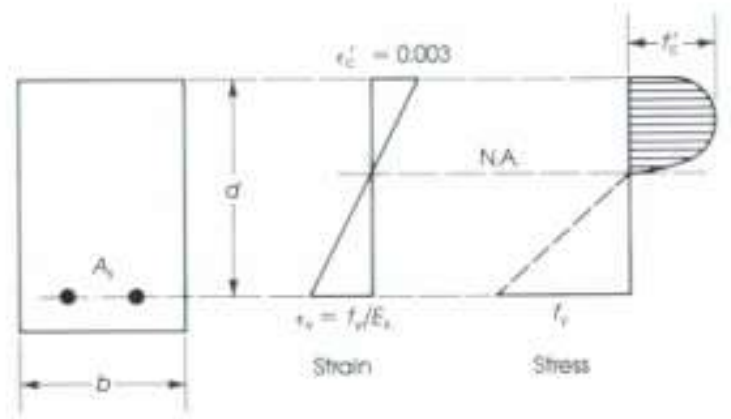

(b)

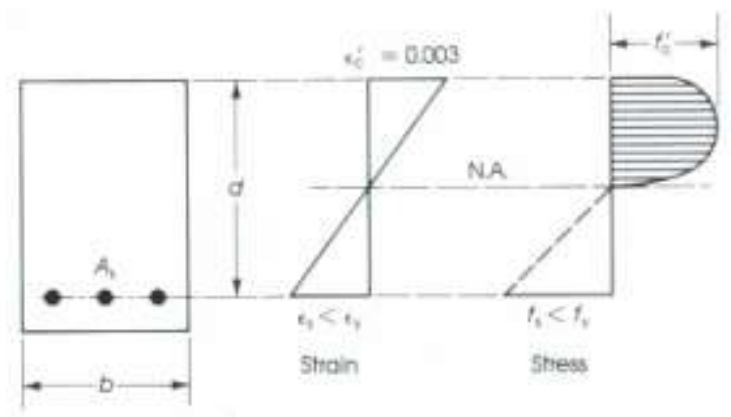

(c)

Fig. 1.1 Stress-Strain block parameters for balanced section 


\subsection{Behavior of RCC Beam in Flexure}

Bending is almost always encountered in structural parts adore beams, slabs, plates and shells that rectangular measure sheer loaded. Flexure moreover happens in columns and walls that rectangular measure subjected to eccentric loading, lateral pressures and lateral displacements.

Flexure commonly happens in conjunction with transversal shear, and most of the time along side extraordinary structural actions, adore axial compression (or tension) and torsion.

\subsection{Steps Involved in the Experimental Work}

The steps concerned within the experimental investigations allotted are

1. Characterization of materials used for the Experimental work.

2. Mix Design for the grades of concrete proposal-about for the study.

3. Design of RC Beam for flexure and shear as per IS 456:2000.

4. Finding out the latest houses, casting of cubes, beams and motion it.

5. Trying out of cubes for its compressive strength for motion periods of three, 7 and 28 days.
6. Checking out of RCC Beams for flexural conduct, in simple terms supported beam under a pair of motive loading situation.

7. Recording deflection at a steady increment of loading, crack development and failure lots, tabulation of outcome and discussions.

8. Scope of the long run learns.

\section{CHARACTERISATION OF MATERIALS}

The following are the principal elements of materials used for concrete mix, houses of the materials and combination proportioning used for this investigation.

\subsection{Foundry Sand}

Foundry sand from Sunrise casting yard, Peenya II stage, Bangalore was used for replacement. The bodily residences and sieve analysis are proven in below desk 2.1 and table 2.2

\subsection{Physical Properties of Foundry sand}

\begin{tabular}{|l|l|l|}
\hline $\begin{array}{l}\text { SL } \\
\text { NO. }\end{array}$ & PROPERTIES & VALUES \\
\hline 1 & Specific gravity & 2.55 \\
\hline 2 & Water absorption & $1.22 \%$ \\
\hline 3 & Finess modulus & 3.19 \\
\hline
\end{tabular}

Table 2.2 Sieve analysis of Foundry sand

\begin{tabular}{|l|l|l|l|l|l|}
\hline $\begin{array}{l}\text { SL } \\
\text { NO. }\end{array}$ & $\begin{array}{l}\text { SIEVE } \\
\text { SIZE } \\
(\mathbf{m m})\end{array}$ & $\begin{array}{l}\text { MASS } \\
\text { RETAINED } \\
(\mathbf{g m})\end{array}$ & $\begin{array}{l}\text { PERCENTAGE } \\
\text { RETAINED }\end{array}$ & $\begin{array}{l}\text { CUMULATIVE } \\
\text { PERCENTAGE RETAINED }\end{array}$ & $\begin{array}{l}\text { PERCENTAGE } \\
\text { PASSING }\end{array}$ \\
\hline 1. & 4.75 & 3 & 0.3 & 0.3 & 99.7 \\
\hline 2. & 2.36 & 9 & 0.9 & 1.2 & 98.8 \\
\hline 3. & 1.18 & 36 & 3.6 & 1.8 & 95.2 \\
\hline 4. & 0.600 & 179 & 17.9 & 22.7 & 77.3 \\
\hline 5. & 0.300 & 456 & 45.6 & 16.3 & 31.7 \\
\hline 6. & 0.150 & 236 & 23.6 & 91.9 & 8.1 \\
\hline 7. & Pan & 12 & 1.2 & 99.5 & 0.5 \\
\hline
\end{tabular}

$\sum \mathbf{f}=\mathbf{4 2 3 . 3}$

Finesse modulus $=\sum$ Cumulative $\%$ retained $/ 100$

$=423.3 / 100=4.233$

Thus Sand conforming to zone II as per IS-383-1970.

\section{MIX PROPORTIONING OF CONCRETE}

Mix design can be summarized as follows.

- Arriving on the target mean strength from the attribute strength reminiscent of.

- Decide on the W/C quantitative relation for goal imply force and checking for specifications of workability.

- Arriving at the water content for the distinctive workability.
- Calculating cement content and verify for the requisites of sturdiness.

- Opt for relative proportion of aggregates from the traits of coarse and nice aggregates.

- Arrive at concrete mix proportions for the important trial combine.

Conducting the trial mixes with proper alterations to induce a cohesive and executable concrete

\section{REINFORCEMENT DETAILS}

High yield force deformed bars of diameter $20 \mathrm{~mm}$ for fundamental metal, diameter $8 \mathrm{~mm}$ was used as anchor bars verified to IS: 1786 (Grade Fe 500) have been used. 

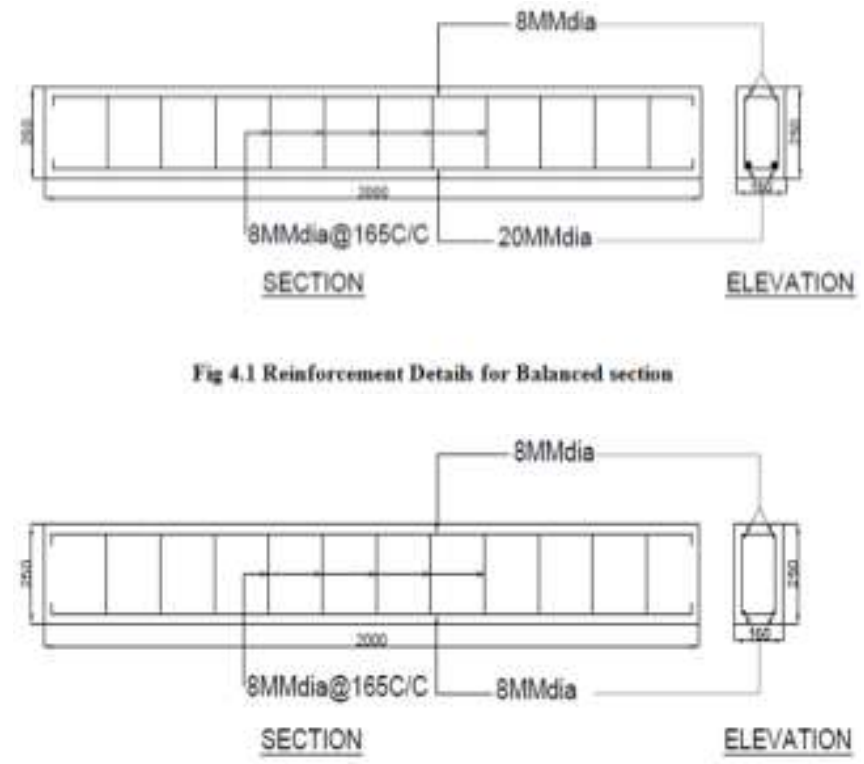

Fig 4.2 Reinforcement Details for minimum section

\section{TESTS FOR COMPRESSIVE FORCE OF CONCRETE SPECIMEN}

Tech ref: IS: 516 - 1959, Reef 1999 is that the code of reference used for deciding upon the compressive strength of concrete specimens. The range of concrete houses could also be with regards to the concrete compressive strength the one concrete engineering property that is habitually akin to and proven.

Checking out computer - The checking out laptop might also be of any safe sort of ample capability for the assessments and in a position of applying the burden at the speed reminiscent of.

\subsection{Flexural Strength of RCC Beam}

BEAM MEASUREMENT AND VARIETY OF BEAMS

RC beams of $150 \mathrm{~mm} \mathrm{X} \mathrm{250mm} \mathrm{X} \mathrm{2000mm} \mathrm{total} \mathrm{and}$ $150 \mathrm{~mm}$ X $219 \mathrm{~mm}$ X $1800 \mathrm{~mm}$ strong had been casted. Fully 16 beams had been casted for M50 grades of concrete with reinforcing conditions such as, balanced and minimal reinforcement.

\subsection{Casting of Beam Specimens for Flexural Force}

\section{Investigate}

The beam formworks have been lined with oil on their inner surfaces and have been positioned on a stage. Reinforcement cages are equipped and had been placed inside the formwork like the duvet block of $31 \mathrm{~mm}$. The reinforcement cage was once positioned within the formwork. The quantity of materials wanted for manufacturing quantity of cubes and concrete beam specimens have been weighed. The materials had been 1 st mixed within the dry situation so mixed fully inside the machine. Concrete is poured into the moulds in 3 layers; every layer was once most likely compacted by means of exploitation tamping rods.
6 beams had been casted for each kind of mix; the best possible surface was swimmingly finished exploitation trowel. After 24 hours RC beam specimens have been remolded and in addition the specimens were curing for 28 days.

\subsection{Flexural Test on Beam Specimens}

\subsubsection{Test Set Up}

The beams were cleansed and white washed with a skinny coat of lime to facilitate the detection and propagations of cracks effectively with sensible appearance. The role at that 2 purpose countless numbers to be utilized, dial gauges to be fixed were marked.

\subsubsection{Loading Body}

A loading frame of fifty-tonnes capability was used for checking out of the beam specimens. The supports of beams had been fabricated from low-carbon steel. These helps were positioned on the channel section of the loading frame that can well be adjusted for the favored span.

The loading frame that was stiffened on its projection And web by means of MS plates as an attitude section was severally accustomed practice the load at the center as 2 motive 1000s on the examine beams. Strong MS rollers of $32 \mathrm{~mm}$ diameter and $220 \mathrm{~mm}$ size were used for transfer of beams. Linearly varying deflection transformer [LVDT] of two number were used at mid and 1/third spans to note down the deflection because the applied.

\section{PROPERTIES OF HARDENED CONCRETE}

\begin{tabular}{|c|c|c|c|c|}
\hline \multirow{2}{*}{ SL.NO } & \multirow{2}{*}{$\begin{array}{l}\text { \% OF } \\
\text { FOUNDRY } \\
\text { SAND }\end{array}$} & \multicolumn{3}{|c|}{$\begin{array}{l}\text { COMPRESSIVE } \\
\text { STRENGTH IN N/MM } \\
\end{array}$} \\
\hline & & 7 days & 14 days & 28 days \\
\hline 1 & $0 \%$ & 22.76 & 25.55 & 32.22 \\
\hline 2 & $15 \%$ & 23.92 & 26.49 & 33.98 \\
\hline 3 & $25 \%$ & 25.86 & 27.64 & 34.33 \\
\hline 4 & $35 \%$ & 27.50 & 29.24 & 34.98 \\
\hline
\end{tabular}

Fig 6.1 Compressive strength of concrete for M50 mix at 7,14 and 28 days

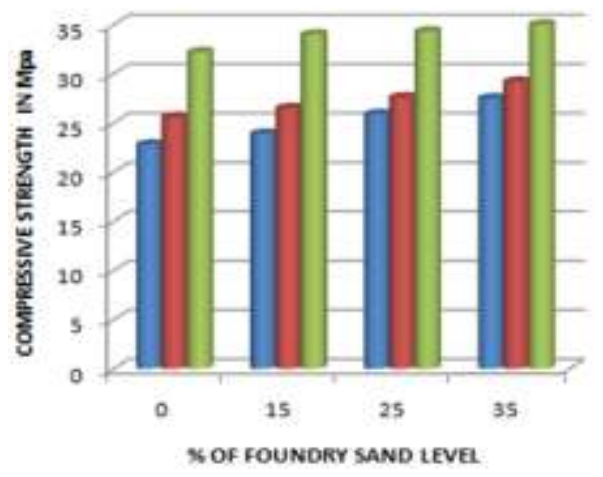

D 7 DAYS STRENGTH = 14 OAYS STRENGTH $=28$ OAYS STRENGTH 


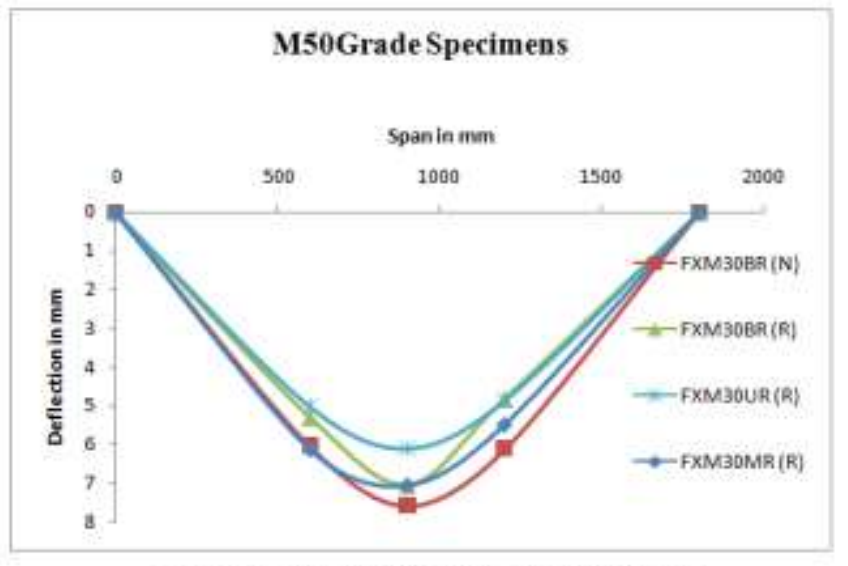

Fig 7.2 Deflection vis Span for M50 Grade Specimens

\section{CONCLUSION}

From the elaborated dialogue of the determine results of M50 grade concrete in RCC beams, the subsequent conclusions were created.

1. Foundry sand conforms to ZONE II and has a number of finer content material than common River Sand.

2. Specific gravity 2.55 , under that of normal River Sand (2.52).

3. The compressive force of foundry sand changed concrete used to be observed to be greater than that of ordinary concrete at curing durations of 7, 14 and 28 days, for M50 grade of concrete.

4. Compressive force increase when replacement of used Foundry sand percent raises when compared to common concrete.

5. From Compressive strength, replacement of exceptional mixture with this used Foundry sand material presents highest Compressive force at $35 \%$ alternative.

6. Use of foundry sand in concrete can retailer the ferrous and non ferrous steel industries disposal, cost and produce a 'greener' concrete for building.

8. Failure load of foundry sand replaced concrete beams had been moderately better than that of ordinary Concrete beams.

\section{ACKNOWLEDGEMENT}

I am thankful to Mr. Shashikumar A and Dr.G Narayana for their guidance. I also thank department of civil engineering S J C institute of technology, chickallapura. And last but not the least my dear friends who have supported me to complete this projet work.

\section{REFERENCES}

[1] IS 383-1970 - Aggregates specification (standards for coarse and exceptional aggregates from ordinary sources of concrete)

[2] IS 2386 phase I - Aggregates trying out (method of test for aggregates for concrete).

[3] IS 12269-1987 - Cement checking out

[4] IS 383:1970 Specification for coarse and first-rate aggregates from normal sources for concrete $(2 \mathrm{~d}$ revision)

[5] IS 456:2000 simple and reinforced concrete - code of apply ( $1 / 3$ revision)

[6] IS 10262:2009 Concrete mix proportioninginstructional materials (first revision)

[7] SP: 34 - Hand publication on Concrete Reinforcement and Detailing.

[8] Http:// fly ash.Sustainablesources.Com

\section{BIOGRAPHIES}

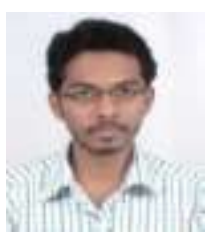

UMASHANKAR A, Pursuing Final Year $\mathrm{M}$ - tech in Infrastructure Engineering and management in SJC institute of Technology, Chickballapur.

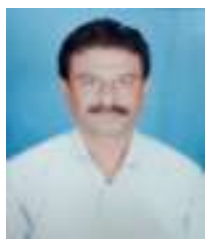

Mr. SHASHIKUMAR A, Assistant Professor, Department of Civil Engineering, SJC institute of Technology, Chickballapur. He has wide experience in teaching field for over 15 years and currently pursuing his $\mathrm{Ph} . \mathrm{D}$.

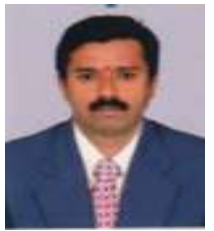

Dr.G NARAYANA, Professor and Head of Civil Engineering Department, SJC institute of Technology, Chickballapur, have a wide experience in teaching and research in Structural Engineering field. He is also a Structural Designer and Consultant for many Projects. 